\title{
Eating disorders among Jordanian adolescents with and without dysglycaemia: a comparative study
}

Huda Al Hourani, ${ }^{1}$ Rana Ababneh, ${ }^{2}$ Nahla Khawaja, ${ }^{2}$ Yousef Khader $^{3}$ and Kamel Ajlouni ${ }^{2}$

${ }^{1}$ Department of Clinical Nutrition and Dietetics, Faculty of Applied Health Sciences, The Hashemite University, Zarqa, Jordan. ${ }^{2}$ National Center for Diabetes, Endocrinology and Genetics, University of Jordan, Amman, Jordan. (Correspondence to: Kamel Ajlouni: ajlouni@ju.edu.jo). ${ }^{3}$ Department of Public Health. Jordan University of Science and Technology, Irbid, Jordan.

\begin{abstract}
Background: Studies on eating disorders among Jordanian adolescents have reported variable prevalence rates of $12-40 \%$. Aims: This study aimed to determine the prevalence of eating disorders among Jordanian adolescents with and without dysglycaemia and determine the associated factors.

Methods: A comparative cross-sectional study was conducted during the period November 2017-February 2018. The Eating Disorder Diagnostic Scale was used to assess the presence of different types of eating disorders, including anorexia nervosa, bulimia nervosa and binge eating disorder. A typical anorexia nervosa and purging disorder were considered "other eating disorders" in this study.

Results: This study included 497 patients with dysglycaemia and 504 age-matched nondysglycaemic participants. Patients with dysglycaemia had a significantly higher prevalence of binge eating disorders compared with nondysglycaemic participants (11.9\% vs 5.8\%, $P$ < 0.001). In dysglycaemia group, adolescents who were aged $\geq 14$ years were more likely to have bulimia nervosa compared with those $<14$ years old. Patients with a sedentary lifestyle were less likely to have bulimia nervosa and binge eating disorders. In the nondysglycaemic group, those aged 14-18 years were more likely to have other eating disorders. Those with dysglycaemia were more likely to have binge eating disorders than those in the nondysglycaemic group $(\mathrm{OR}=2.1,95 \% \mathrm{CI}: 1.3-3.3 ; \mathrm{P}=0.002)$ after adjusting for possible confounders.
\end{abstract}

Conclusions: Adolescents with dysglycaemia had higher prevalence of eating disorders compared with their nondysglycaemic peers. Screening for eating disorders is recommended among adolescents to secure early detection and subsequent intervention.

Citation: Al Hourani H; Ababneh R; Khawaja N; Khader Y Ajlouni K. Eating disorders among Jordanian adolescents with and without dysglycaemia: a comparative study. East Mediterr Health J. 2020;26(12):1502-1509. https://doi.org/10.26719/emhj.20.86

Received: 03/06/19; accepted: 24/12/19

Copyright (c) World Health Organization (WHO) 2020. Open Access. Some rights reserved. This work is available under the CC BY-NC-SA 3.0 IGO license (https://creativecommons.org/licenses/by-nc-sa/3.o/igo).

\section{Introduction}

Eating disorders (EDs) are psychiatric conditions characterized by severe disturbances in eating behaviour that result in significant physiologic impairment and, in some cases, increased mortality in some types $(1,2)$. These conditions have significant health effects on people with diabetes. Many studies have been conducted to determine the association between EDs and type 1 diabetes mellitus (T1DM) and have reported that diabetes is a risk factor (3-5). Eating disorders have been shown to be more frequent in adolescents with diabetes compared with nondiabetic adolescents (6,7). A 2013 meta-analysis showed that EDs were more common in adolescents with T1DM (7.0\%) compared with their adolescents with no diabetes $(2.8 \%)$ (8). Previous research has shown that EDs are more than twice as common in young females with T1DM compared with their nondiabetic peers (9).

The Diagnostic and statistical manual of mental disorders (DSM) specifies a number of diagnoses under "Feeding and eating disorders", including anorexia nervosa (AN), which is characterized by restriction of energy intake relative to requirements, leading to significantly low body weight, and bulimia nervosa (BN), which involves binging followed by purging to prevent weight gain. In 2013, the DSM also officially recognized binge eating disorder (BED) as a distinct eating disorder characterized by the ingestion of too much food in a short time (10).

Adolescents with diabetes are at higher risk of eating disturbances and consequently of higher rates of disease complications; EDs among adolescents with TIDM are associated with poor diabetes control and higher rates of diabetes complications, including ketoacidosis and hospitalization (11).

Studies on EDs among adolescents in the Eastern Mediterranean Region are limited in number and also limited to healthy adolescents. In Egypt, El-Bakry et al. reported that $34.7 \%$ of adolescent patients with T1DM have disordered eating behaviours (12). In Jordan, studies on EDs were limited to healthy female adolescents; these reported variable prevalence rates between $12 \%$ and $40 \%(13-15)$. The prevalence of EDs among Jordanian adolescents with T1DM is unknown; knowing the prevalence is important to help care providers make decisions on screening activities and management. Therefore, this study aimed to determine the prevalence of EDs among Jordanian adolescents with and without 
dysglycaemia and to determine their associated factors.

\section{Methods}

\section{Design and participants}

This cross-sectional comparative study included $497(172$ males and 325 females) patients aged 10-24 years with dysglycaemia (T1DM and pre-DM) who attended the National Center for Diabetes, Endocrinology and Genetics and Jordan University Hospital in Amman from November 2017 to February 2018, and 504 (175 males and 329 females) age-matched nondysglycaemic control participants randomly selected from government schools and universities.

This study was reviewed and approved by the research ethics committee at the National Center for Diabetes, Endocrinology and Genetics. The ethical aspects of the present study are covered in the Declaration of Helsinki.

\section{Inclusion and exclusion criteria}

Only adolescents aged 10-24 years were included in this study. The dysglyacemic group included patients diagnosed with T1DM or pre-DM. Participants were diagnosed as having prediabetes if they had impaired fasting blood glucose (fasting blood glucose $100-125 \mathrm{mg} / \mathrm{dL}$ ) and/ or impaired glucose tolerance (blood glucose 140-199 mg/ $\mathrm{dL} 2$ hours after a 75-g oral glucose tolerance test). The exclusion criteria were: having hypothyroidism, Cushing's syndrome, Addison's disease, growth hormone deficiency, receiving growth hormone therapy and pregnancy.

\section{Sample size}

The sample size was calculated based on the most recent estimate of ED prevalence rate (14). Assuming that prevalence of $\mathrm{ED}$ is $12 \%$, the minimum sample size needed to estimate the prevalence within a margin of error of $5 \%$ at a level of significance of $5 \%$ and power of $80 \%$ was estimated as 163 in each group. The sample size was increased in both groups to have a higher power.

\section{The study tool}

A questionnaire was designed to collect demographic and lifestyle data including age, sex, education level, employment, physical activity level, and duration of dysglycaemia when present. The diagnostic instrument for EDs was the Eating Disorder Diagnostic Scale, a 22-item self-report questionnaire that evaluates the presence of 3 EDs: AN, BN and BED, based on the criteria of the DSM-IV (16). The scale is composed of a combination of Likert scores, dichotomous scores and frequency scores. The questions explored the person's feelings toward his or her appearance and having incidents of eating with a loss of control and how he/she felt after overeating. The estimated time for completing the questionnaire was 30 minutes.

In addition, the questionnaire included questions about the person's experiences of fasting, skipping at least 2 meals, making themselves vomit, and using laxatives or diuretics or being engaged in more intense exercise to prevent weight gain. There were also questions about how much body image problems impact the subject's relationships and friendships with others. The final questions were about the patient's current weight, height, sex and age.

Atypical AN and purging disorder were considered "other EDs". The Eating Disorder Diagnostic Scale has been translated into Arabic and validated by a study done at the National Center for Diabetes, Endocrinology and Genetics in 2010 (17). Cronbach's alpha was 0.80, which is considered acceptable.

\section{Anthropometric measures}

Height was recorded to the nearest $0.5 \mathrm{~cm}$ using a stadiometer, with the subject in a standing position and without shoes. Body weight was recorded to the nearest 0.1 $\mathrm{kg}$ using a calibrated scale. The nondysglycaemic participants' weight and height were measured at their schools or universities. Body mass index (BMI) was calculated using the standard formula: weight $(\mathrm{kg}) /$ height $(\mathrm{m})^{2}$ and classified into severe thinness, underweight, normal weight, overweight and obese. Participants younger than 19 years of age were classified according to the WHO growth charts 2007 .

\section{Metabolic control}

The choice of treatment for those with TiDM was insulin plus metformin or insulin alone, whereas pre-DM patients were treated with metformin. Metabolic control was assessed by $\mathrm{HbAl}_{c}$ levels, measured using the BioRad VARIANT II TURBO HbA1 Kit-2.o (Bio-Rad, Hercules, California), which utilizes the principles of ion-exchange high-performance liquid chromatography.

\section{Statistical analysis}

Analyses were conducted using SPSS, version 21.o. Continuous variables were described using means and standard deviations and categorical variables were described using percentages. The chi-squared test was used to compare percentages. Multiple binary logistic regression analysis was conducted to determine factors associated with EDs and to determine the association between dysglycaemia and EDs. $P$-value $<0.05$ was considered statistically significant.

\section{Results}

\section{Participants' characteristics}

The dysglyacemic group included 497 participants (65.4\% females and $34.6 \%$ males) with a mean age of 16.7 years. The nondysglycaemia group included 504 participants (65.3\% females and $34.7 \%$ males) with a mean age of 16.8 years (Table 1). Of those with dysglycaemia, $45.9 \%$ had T1DM and $54.1 \%$ had pre-DM. The mean BMI was higher in the dysglyacemic group compared with the nondysglycaemia group (25.0 vs $21.2 \mathrm{~kg} / \mathrm{m}^{2}, P<0.001$ ). Just over a quarter of the dysglycaemia group and around $6 \%$ of the nondysglycaemia group were obese. The mean $\mathrm{HbAl}_{c}$ was $8.6 \%$ in the dysglycaemia group. 


\begin{tabular}{|c|c|c|c|}
\hline Characteristic & $\begin{array}{c}\text { Dysglycaemia } \\
(n=497) \\
\text { Mean (SD) }\end{array}$ & $\begin{array}{c}\text { Nondysglycaemia } \\
(n=504) \\
\text { Mean (SD) }\end{array}$ & $P$-value \\
\hline Age (years) & $16.8(4.3)$ & $16.8(4.4)$ & 0.871 \\
\hline Height (cm) & $157.4(12.0)$ & $157.9(13.1)$ & 0.521 \\
\hline Weight (kg) & $63.4(21.0)$ & $53.6(13.9)$ & $<0.001$ \\
\hline BMI $(\mathrm{kg} / \mathrm{m} 2)$ & $25.0(6.6)$ & $21.2(4.0)$ & $<0.001$ \\
\hline Sex, no. (\%) & & & 0.970 \\
\hline Male & $172(34.6)$ & $175(34.7)$ & \\
\hline Female & $325(65.4)$ & $329(65.3)$ & \\
\hline BMI category, no. (\%) & & & $<0.001$ \\
\hline Severe thinness & $1(0.2)$ & $14(2.8)$ & \\
\hline Underweight & $19(3.8)$ & $44(8.7)$ & \\
\hline Normal & $182(36.6)$ & $301(59.7)$ & \\
\hline Overweight & $160(32.2)$ & $116(23.0)$ & \\
\hline Obese & $135(27.2)$ & $29(5.8)$ & \\
\hline Physical activity ${ }^{a}$, no. (\%) & & & 0.001 \\
\hline Sedentary & $284(57.1)$ & $234(46.4)$ & \\
\hline Active & $213(42.9)$ & $270(53.6)$ & \\
\hline
\end{tabular}

$S D=$ standard deviation; $B M I=$ body mass index

${ }^{a}$ Physical activity was classified according to the International Physical Activity Questionnaire (sedentary: physical activity $\leq 10$ continuous minutes per week and up to 150 minutes per week. active: moderate to high activity like walking for $\geq 5$ days/week and $\geq 30$ minutes per session).

\section{Prevalence of eating disorders}

Those with dysglycaemia showed a higher prevalence of BED compared with those who did not have nondysglycaemia $(11.9 \%$ vs $5.8 \%, P<0.001)$ (Table 2$)$. However, there were no significant differences in the prevalence of $\mathrm{BN}$ and other EDs between the 2 groups.

Table 3 shows the prevalence of EDs in both groups according to the participants' characteristics. For the nondysglycaemia group, BED was significantly more prevalent among females and the other EDs were less common among those who were 14-18 years old. In the dysglyacemic group, the prevalence was higher among older adolescents, females, obese patients, the physically inactive, and patients with pre-DM. Higher BMI, sedentary lifestyle, and pre-DM were statistically significantly associated with BED.

\section{Multiple regression analysis}

Table 4 shows the multiple regression analysis of factors associated with different types of EDs. In the dysglycae- mia group, adolescents aged $\geq 14$ years were more likely to have BN compared with those $<14$ years old. Age was not significantly associated with the other 2 types of ED. Patients who reported having a sedentary lifestyle were less likely to have $\mathrm{BN}(\mathrm{OR}=0.2,95 \% \mathrm{CI}: 0.1-0.5 ; \mathrm{P}=0.001)$ and BED (OR $=0.4,95 \%$ C: $0.2-0.8 ; P=0.005)$.

In the nondysglycaemic group, participants who were aged $14-18$ years were 2.6 times more likely to have other EDs compared with those $<14$ years $(P=0.014)$. Also in this group, a physical activity was not significantly associated with the 3 different types of ED.

A separate analysis (after adjusting for possible confounders) showed that those with dysglycaemia were 2.1 times more likely to have BED than the nondysglycaemic group $(\mathrm{OR}=2.1,95 \% \mathrm{CI}: 1.3-3.3 ; \mathrm{P}=$ 0.002).

\section{Discussion}

In this study, we estimated the prevalence of EDs among dysglycaemic and nondysglycaemic adolescents in Jordan. The prevalence of EDs was higher in dysglycaemic

\begin{tabular}{|c|c|c|c|}
\hline Disorder & $\begin{array}{c}\text { Dysglycaemia } \\
(n=497) \\
\%\end{array}$ & $\begin{array}{c}\text { Nondysglycaemia } \\
(n=504) \\
\%\end{array}$ & P-value \\
\hline Bulimia nervosa & 6.6 & 4.9 & 0.158 \\
\hline Binge eating disorder & 11.9 & 5.8 & $<0.001$ \\
\hline Other eating disorder & 17.1 & 13.9 & 0.094 \\
\hline Any eating disorder & 35.7 & 25.0 & $<0.001$ \\
\hline
\end{tabular}




\begin{tabular}{|c|c|c|c|c|c|c|}
\hline \multirow[t]{2}{*}{ Characteristic } & \multicolumn{3}{|c|}{ Dysglycaemia } & \multicolumn{3}{|c|}{ Nondysglycaemia } \\
\hline & $\begin{array}{c}\text { Bulimia } \\
\text { nervosa } \\
(n=33) \\
\text { No. }(\%)\end{array}$ & $\begin{array}{c}\text { Binge eating } \\
\text { disorder } \\
(n=59) \\
\text { No. }(\%)\end{array}$ & $\begin{array}{c}\text { Other eating } \\
\text { disorders } \\
(\mathbf{n}=85) \\
\text { No. (\%) }\end{array}$ & $\begin{array}{c}\text { Bulimia } \\
\text { nervosa } \\
(n=25) \\
\text { No. }(\%)\end{array}$ & $\begin{array}{c}\text { Binge eating } \\
\text { disorder } \\
(n=29) \\
\text { No. }(\%)\end{array}$ & $\begin{array}{c}\text { Other eating } \\
\text { disorders } \\
(\mathbf{n}=\mathbf{7 0}) \\
\text { No. }(\%)\end{array}$ \\
\hline \multicolumn{7}{|l|}{ Age (years) } \\
\hline$<14$ & $3(1.8)$ & $13(7.8)$ & $30(18.1)$ & $7(4.2)$ & $8(4.8)$ & $25(15.1)$ \\
\hline $14-18$ & $12(8.0)$ & $22(14.7)$ & $19(12.7)$ & $5(3.3)$ & $5(3.3)$ & $10(6.6)$ \\
\hline$>18$ & $18(9.9)$ & $24(13.3)$ & $36(19.9)$ & $13(7.0)$ & $16(8.6)$ & $35(18.8)$ \\
\hline$P$-value & 0.007 & 0.132 & 0.204 & 0.257 & 0.093 & 0.005 \\
\hline \multicolumn{7}{|l|}{ Sex } \\
\hline Male & $7(4.1)$ & 19 (11.0) & $23(13.4)$ & $6(3.4)$ & $3(1.7)$ & $18(10.3)$ \\
\hline Female & $26(8.0)$ & $40(12.3)$ & $62(19.1)$ & $19(5.8)$ & $26(7.9)$ & $52(15.8)$ \\
\hline$P$-value & 0.094 & 0.679 & 0.108 & 0.248 & 0.005 & 0.088 \\
\hline \multicolumn{7}{|l|}{ BMI category } \\
\hline Severe thinness & $0(0.0)$ & $0(0.0)$ & $0(0.0)$ & $1(7.1)$ & $1(7.1)$ & $0(0.0)$ \\
\hline Underweight & $0(0.0)$ & $1(5.3)$ & $2(10.5)$ & $0(0.0)$ & $1(2.3)$ & $1(2.3)$ \\
\hline Normal & $3(1.6)$ & $18(9.9)$ & $24(13.2)$ & $15(5.0)$ & $15(5.0)$ & $43(14 \cdot 3)$ \\
\hline Overweight & $12(7.5)$ & $10(6.3)$ & $32(20.0)$ & $7(6.0)$ & $10(8.6)$ & $22(19.0)$ \\
\hline Obese & $18(13.3)$ & $30(22.2)$ & $27(20.0)$ & $2(6.9)$ & $2(6.9)$ & $4(13.8)$ \\
\hline$P$-value & $<0.001$ & $<0.001$ & 0.342 & 0.614 & 0.436 & 0.045 \\
\hline \multicolumn{7}{|l|}{ Physical activity ${ }^{a}$} \\
\hline Sedentary & $29(10.2)$ & $44(15.5)$ & $52(18.3)$ & $13(5.6)$ & $13(5.6)$ & $36(15.4)$ \\
\hline Active & $4(1.9)$ & $15(7.0)$ & $33(15.5)$ & $12(4.4)$ & $16(5.9)$ & $34(12.6)$ \\
\hline$P$-value & $<0.001$ & 0.004 & 0.409 & 0.567 & 0.859 & 0.366 \\
\hline \multicolumn{7}{|c|}{ Type of dysglycaemia } \\
\hline TiDM & $8(3.6)$ & $19(8.3)$ & $40(17.5)$ & - & - & - \\
\hline Pre-DM & $25(9.3)$ & $40(14.9)$ & $45(16.7)$ & & & \\
\hline$P$-value & 0.010 & 0.025 & 0.810 & & & \\
\hline
\end{tabular}

BMI = body mass index; TIDM = type 1 diabetes mellitus; Pre-DM = pre-diabetes mellitus.

aPhysical activity was classified according to the International Physical Activity Questionnaire (sedentary: physical activity $\leq 10$ continuous minutes per week and up to 150 minutes per week. active: moderate to high activity like walking for $\geq 5$ days/week and $\geq 30$ minutes per session).

patients compared with nondysglycaemic participants (35.7\% vs $25.0 \%$ ). The EDs identified in this study included $\mathrm{BN}, \mathrm{BED}$, and other EDs; no cases of AN were identified in either group. The finding of higher prevalence of EDs among patients with dysglycaemia is consistent with the findings of other studies $(4,7,18)$. Young et al. reported that the prevalence of EDs in adolescents with T1DM was greater compared with their nondiabetic counterparts (7\% vs $2.8 \%$ ) (8). Jones et al. found that EDs were more prevalent in females with diabetes $(10 \%)$ than in nondiabetic females (4\%) (9). Some research has indicated that diabetes is associated with psychosocial difficulties and worries (19). This might explain the higher prevalence of EDs among those without diabetes, especially adolescents and young adults.

In the current study, the most common eating disorder seen in the dysglycaemic patients was BED, which is the most common ED worldwide when compared with AN and $\mathrm{BN}(20,21)$. The prevalence of BED in community samples ranges from $2 \%$ to $5 \%$ (22). We found that patients with dysglycaemia were 2 times more likely to have BED than the nondysglycaemic group. This finding is consistent with previous research (23). Mannucci et al. reported that the prevalence of BED was $4.9 \%$ in IDDM, patients and $2.7 \%$ in controls (24). d'Emden et al. reported that $17.7 \%$ of Australian adolescents with T1DM had BED (25). It was also more common in preteens and early teenage girls with T1DM than in nondiabetic girls $3.0 \%$ vs $0.3 \%$ ) (26). Although EDs can affect individuals of all ages, adolescence represents a peak lifetime period of increased vulnerability for the onset of EDs; BED has 2 peaks of onset, the first at a mean age of 14 years and the second between 19 and 24 years old (27). The age range for the current study was 10-24 years, and the mean age was 16 years, which might explain the reason that BED was the most common ED in this group.

Obesity is known as a risk factor for inappropriate weight control practices, and is therefore a risk factor for 


\begin{tabular}{|c|c|c|c|c|c|c|}
\hline \multirow[t]{2}{*}{ Characteristic } & \multicolumn{2}{|c|}{ Bulimia nervosa } & \multicolumn{2}{|c|}{ Binge eating disorder } & \multicolumn{2}{|c|}{ Other eating disorders } \\
\hline & OR $(95 \% \mathrm{CI})$ & P-value & OR $(95 \% \mathrm{CI})$ & P-value & OR $(95 \% \mathrm{CI})$ & P-value \\
\hline & \multicolumn{6}{|c|}{ Dysglycaemic group } \\
\hline \multicolumn{7}{|l|}{ Age (year) } \\
\hline$<14$ & 1.0 & & 1.0 & & 1.0 & \\
\hline $14-18$ & $4.7(1.3-17.3)$ & 0.018 & $2.0(0.9-4.2)$ & 0.060 & $1.5(0.8-2.8)$ & 0.183 \\
\hline$>18$ & $5.9(1.7-20.5)$ & 0.005 & $1.8(0.8-3.6)$ & 0.122 & $0.9(0.6-1.5)$ & 0.673 \\
\hline \multicolumn{7}{|l|}{ Physical activity } \\
\hline Active & 1.0 & & 1.0 & & 1.0 & \\
\hline Sedentary & $0.2(0.1-0.4)$ & 0.001 & $0.4(0.2-0.8)$ & 0.005 & $1.2(0.8-2.0)$ & 0.413 \\
\hline \multicolumn{7}{|c|}{ Non-dysglycaemic group } \\
\hline \multicolumn{7}{|l|}{ Age (years) } \\
\hline$<14$ & 1.0 & & 1.0 & & 1.0 & \\
\hline $14-18$ & $0.7(0.2-2.4)$ & 0.625 & $0.9(0.2-2.2)$ & 0.522 & $2.6(1.2-5.8)$ & 0.014 \\
\hline$>18$ & $1.6(0.6-4.3)$ & 0.310 & $1.9(0.9-4.6)$ & 0.155 & $0.8(0.4-1.4)$ & 0.458 \\
\hline \multicolumn{7}{|l|}{ Physical activity } \\
\hline Active & 1.0 & & 1.0 & & 1.0 & \\
\hline Sedentary & $0.8(0.4-1.9)$ & 0.640 & $1.1(0.5-2.4)$ & 0.751 & $1.3(0.8-2.2)$ & 0.321 \\
\hline
\end{tabular}

ED. The EDs that have been most frequently studied in obese individuals are BED and BN (28). In our study, obese people with dysglycaemia showed a higher prevalence of BED and BN than overweight, normal weight and underweight participants; about $30 \%$ of the dysglycaemic participants who had BED were either overweight or obese.

Several studies have identified factors that increase the risk of developing psychiatric problems that lead to EDs $(29,30)$. These include age, female sex, increased body weight, body image dissatisfaction, history of dieting and history of depression. In the current study, age and physical activity were associated with BN and BED in the dysglycaemic group. Takii et al: reported that individuals with T1DM with an onset between age 7 and 18 years were at significantly higher risk of subsequently developing EDs such as AN or BN than those who were diagnosed before 7 or after 18 years of age (31). The association of age with EDs in this study is in agreement with previous research $(9,32)$; patients older than 18 years were 5 times more likely to have BN than young patients who were less than 14 years old. In the nondysglycaemic group, age was the only factor associated with other EDs such as atypical AN and purging disorders. Participants between 14-18 years old were 2.6 times more likely to have other EDs. Adolescence is a critical period of human development during which several physical and psychological changes occur, and peer influences and the continuous use of social media may increase the risk of developing EDs in this age group.

In the nondysglycaemic group, females were 4 times more likely to have BED compared with males. Studies conducted on BED have shown that girls had a higher risk than boys $(33,34)$. Research in Jordan has also shown that the prevalence of EDs was higher among females compared with males (13,14). Generally, females are very concerned about their weight, and it is somewhat common for adolescent girls to engage in inappropriate weight management such as using laxatives, fasting and vomiting (35). Moreover, females are more likely to report eating-related distress or loss of control because expressing emotions is sometimes more socially accepted and expected from females (36). However, it is also possible that males may not feel distressed or out of control when they overeat.

Physical activity is another risk factor for EDs. Individuals with BED are commonly described as sedentary (37,38). In the current study, dysglycaemic patients who had a sedentary lifestyle had a higher prevalence of BED and BN than patients with an active lifestyle, which might be due to a number of factors, such as psychological and emotional factors, negative body attitude, social support, and the financial cost of the exercise facility. Moreover, participants with a sedentary lifestyle are less likely to develop BED and BN than people with an active lifestyle, which might be due to the fact that people with BED consider exercise a factor that allows them to eat greater quantities of food without getting fat, while people with $\mathrm{BN}$ use exercise as a way to overcome excessive food consumption. Individuals with BED have been described as sedentary, whereas the opposite has been the case for those with BN (38).

As a final point, the prevalence of EDs among diabetic patients showed incongruities. Many screening tools have been used to assess the existence of EDs; however, they were used for different age groups and not designed for people who have medical conditions such as diabetes. Thus, these tools might not display the actual 
estimate of EDs and might lead to a misclassification of eating disorder risks in those with chronic illness. Another limitation of this study is inherent in the cross-sectional design: causality cannot be established using this design. Further studies with the appropriate design are needed to establish the causal link between dysglycaemia and EDs.

\section{Conclusion}

Adolescents with dysglycaemia showed a higher prevalence of EDs compared with their nondysglycaemic peers even though the diagnosis of EDs in individuals with di- abetes is difficult due to the frequent disguise and denial of disordered eating behaviour. Therefore, care providers must pay attention to warning signs such as poor glycaemic control and a refusal to be weighed. Screening is recommended to secure early detection and subsequent intervention.

Funding: This study was funded by the National Center for Diabetes, Endocrinology and Genetics, Amman, Jordan.

Competing interests: None declared.

\section{Étude comparative sur les troubles alimentaires chez les adolescents jordaniens avec et sans dysglycémie}

\section{Résumé}

Contexte : Des études sur les troubles alimentaires chez les adolescents jordaniens ont fait état de taux de prévalence variables compris entre 12 et $40 \%$.

Objectifs : La présente étude visait à déterminer la prévalence des troubles alimentaires chez les adolescents jordaniens avec et sans dysglycémie et à déterminer les facteurs qui y sont associés.

Méthodes : Une étude transversale comparative a été menée au cours de la période allant de novembre 2017 à février 2018. L'échelle de diagnostic des troubles alimentaires a été utilisée pour évaluer la présence de différents types de troubles alimentaires, notamment l'anorexie mentale, la boulimie et l'hyperphagie boulimique. L'anorexie nerveuse atypique et le trouble de purge ont été considérés en tant « qu'autres troubles alimentaires » dans cette étude.

Résultats : Cette étude portait sur 497 patients atteints de dysglycémie et 504 participants sans dysglycémie appariés selon l'âge. Les patients atteints de dysglycémie présentaient une prévalence significativement plus élevée de troubles de la boulimie par rapport aux participants sans dysglycémie $(11,9 \%$ contre $5,8 \%, p<0,001)$. Les adolescents atteints de dysglycémie âgés de 14 ans ou plus étaient plus susceptibles de souffrir de boulimie nerveuse que ceux de moins de 14 ans. Les patients ayant un mode de vie sédentaire étaient moins susceptibles de souffrir de boulimie et d'hyperphagie boulimique. Dans le groupe des sujets non dysglycémiques, la probabilité d'avoir d'autres troubles alimentaires était plus élevée ceux âgés de 14 à 18 ans. Les participants atteints de dysglycémie étaient plus susceptibles d'avoir une hyperphagie boulimique que ceux du groupe non dysglycémique ( $\mathrm{OR}=2,1$, IC à $95 \%: 1,3-3,3 ; p=0,002$ ) après ajustement en fonction des facteurs de confusion possibles.

Conclusions : Les adolescents atteints de dysglycémie présentaient une prévalence plus élevée de troubles alimentaires par rapport à leurs pairs non atteints de dysglycémie. Le dépistage des troubles alimentaires est recommandé chez les adolescents afin d'assurer une détection précoce et une intervention ultérieure.

$$
\begin{aligned}
& \text { اضطر ابات الأكل بين المراهقين الأردنيين المصابين بخلل سكر الدم وغير المصابين به: دراسة مقارنة } \\
& \text { هدى الحوراني، رنا أبابنة، نهلة خو اجة، يوسف خضر، كامل العجلوني } \\
& \text { الخالاصنة } \\
& \text { الخلفية: أفادت الدراسات التي أجريت على اضطر ابات الأكل بين المراهقين الأردنين أن معدلات الانتشار المتغيرة تتراوح بين } 12 \text { - } 40 \text {. } \\
& \text { الأهداف: هدفت هذه الدر اسة إلى تحديد معدل انتشار اضطر ابات الأكل بين المراهقين الأردنيين المصابين بخلل سكر الدم وغير المصابين به، وتحديد } \\
& \text { العوامل المرتبطة بذلك. مدفت هله }
\end{aligned}
$$

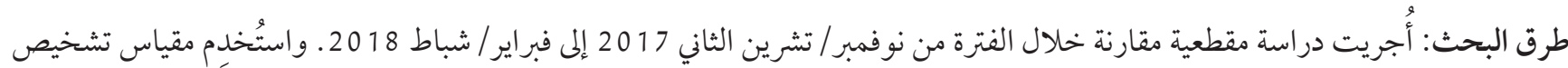

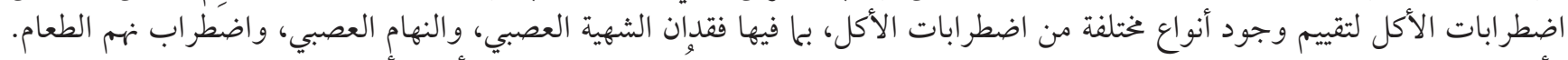

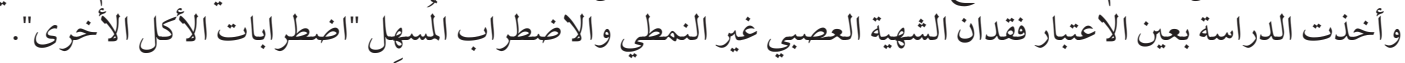

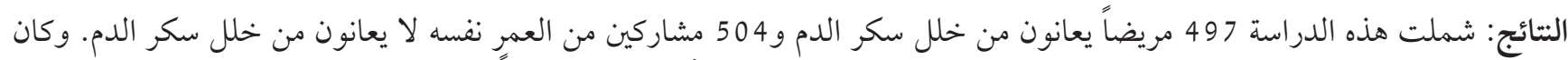

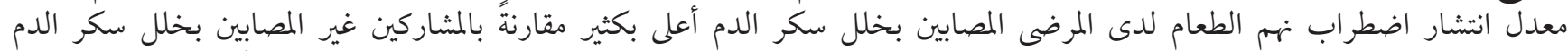

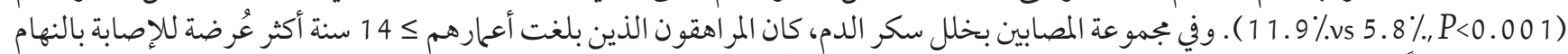

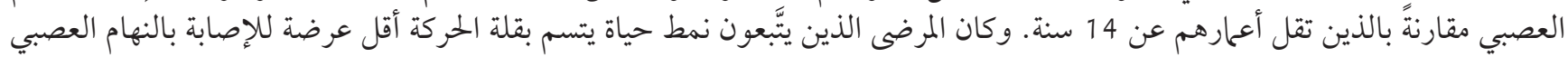




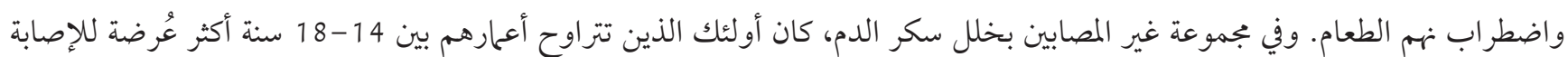

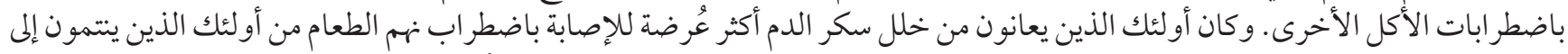

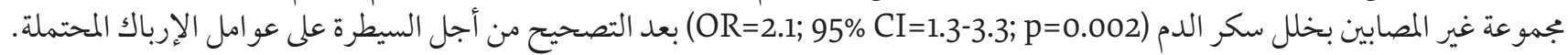

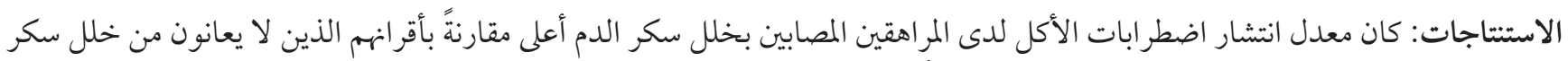

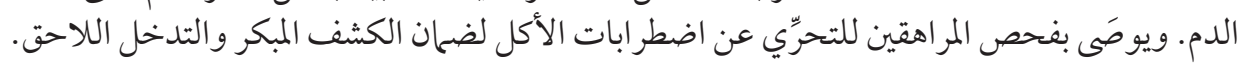

\section{References}

1. Brown KL, LaRose JG, Mezuk B. The relationship between body mass index, binge eating disorder and suicidality. BMC Psychiatry. 2018;18(1):196. doi:10.1186/s12888-018-1766-z

2. McElroy SL, Crow S, Biernacka JM, Winham S, Geske J, Cuellar Barboza AB, et al. Clinical phenotype of bipolar disorder with comorbid binge eating disorder. J Affect Disord. 2013 Sep 25;150(3):981-6. doi:10.1016/j.jad.2013.05.024

3. Toni G, Berioli MG, Cerquiglini L, Ceccarini G, Grohmann U, Principi N, et al. Eating disorders and disordered eating symptoms in adolescents with type 1 diabetes. Nutrients. 2017 Aug 19;9(8). doi:10.3390/nu908090

4. Berger G, Waldhoer T, Barrientos I, Kunkel D, Rami-Merhar BM, Schober E, et al. Association of insulin-manipulation and psychiatric disorders: A systematic epidemiological evaluation of adolescents with type 1 diabetes in Austria. Pediatr Diabetes. 2019 Feb;20(1):127-36. doi:10.1111/pedi.12784

5. $\quad$ Wisting L, Reas DL, Bang L, Skrivarhaug T, Dahl-Jorgensen K, Ro O. Eating patterns in adolescents with type 1 diabetes: associations with metabolic control, insulin omission, and eating disorder pathology. Appetite. 2017;114:226-31. doi:10.1016/j.appet.2017.03.035

6. Goncalves S, Barros V, Rui Gomes A. Eating-disordered behaviour in adolescents with type 1 diabetes. Can J Diabetes. 2016 Apr;40(2):152-7. doi:10.1016/j.jcjd.2015.09.011

7. $\quad$ Alice Hsu YY, Chen BH, Huang MC, Lin SJ, Lin MF. Disturbed eating behaviors in Taiwanese adolescents with type 1 diabetes mellitus: a comparative study. Pediatr Diabetes. 2009 Feb;10(1):74-81. doi:10.1111/j.1399-5448.2008.00422.x

8. Young V, Eiser C, Johnson B, Brierley S, Epton T, Elliott J, et al. Eating problems in adolescents with Type 1 diabetes: a systematic review with meta-analysis. Diabet Med. 2013 Feb;30(2):189-98. doi:10.1111/j.1464-5491.2012.03771.X

9. Jones JM, Lawson ML, Daneman D, Olmsted MP, Rodin G. Eating disorders in adolescent females with and without type 1 diabetes: cross sectional study. BMJ. 2000;320:1563-6. PMID:1084596

10. Banting R, Randle-Phillips C. A systematic review of psychological interventions for comorbid type 1 diabetes mellitus and eating disorders. Diabetes Manag. 2018;8:1-18.

11. Scheuing N, Bartus B, Berger G, Haberland H, Icks A, Knauth B, et al.. Clinical characteristics and outcome of 467 patients with a clinically recognized eating disorder identified among 52,215 patients with type 1 diabetes: a multicenter German/Austrian study. Diabetes Care. 2014;37:1581-9. doi:10.2337/dc13-2156

12. El-Bakry A, Mahmoud A, Kamal A, Madbouly N, Ayoub D, Kamel R. Disordered eating behaviors among adolescent patients with type I diabetes mellitus. Egypt J Psychiatr. 2018;39:127-32.

13. Al-Kloub M, Al-Khawaldeh O, ALBashtawy M, Batiha A, Al-Haliq M. Disordered eating in Jordanian adolescents. Int J Nurs Pract. 2019;25(1):e12694. doi:10.1111/ijn.12694

14. Alfoukha M, Hamdan-Mansour A, Banihani M. Social and psychological factors related to risk of eating disorders among high school girls. J Sch Nurs. 2019 Jun;35(3):169-77. doi:10.1177/1059840517737140

15. Mousa TY, Al-Domi HA, Mashal RH, Jibril MA. Eating disturbances among adolescent schoolgirls in Jordan. Appetite. 2010 Feb;54(1):196-201. doi:10.1016/j.appet.2009.10.008

16. Stice E, Telch CF, Rizvi SL. Development and validation of the Eating Disorder Diagnostic Scale: a brief self-report measure of anorexia, bulimia, and binge-eating disorder. Psychol Assess. 2000 Jun;12(2):123-31. doi:10.1037//1040-3590.12.2.123

17. Sunna'a M. The prevalence of certain eating disrders and its influnces on glycemic control among Jordainian adult females with type 2 diabetes mellitus in National Center for Diabetes, Endocrinology and Genetics [thesis]. Amman: University of Jordan; 2013:67.

18. Reinehr T, Dieris B, Galler A, Teufel M, Berger G, Stachow R, et al. Worse metabolic control and dynamics of weight status in adolescent girls point to eating disorders in the first years after manifestation of type 1 diabetes mellitus: findings from the Diabetes Patienten Verlaufsdokumentation Registry. J Pediatr. 2019;207:205-12. doi:10.1016/j.jpeds.2018.11.037

19. Bachle C, Lange K, Stahl-Pehe A, Castillo K, Scheuing N, Holl RW, et al. Symptoms of eating disorders and depression in emerging adults with early-onset, long-duration type 1 diabetes and their association with metabolic control. PLoS One. 2015;10:e0131027. doi:10.1371/journal.pone.0131027

20. Granje J. Binge eating disorder (BED): nutritional prevention and treatment. J Food Nutr Disor. 2018;7(2):12.

21. Tareen RS, Tareen K. Psychosocial aspects of diabetes management: dilemma of diabetes distress. Transl Pediatr. 2017 Oct;6(4):383-96. doi:10.21037/tp.2017.10.04 
22. Peterson RE, Latendresse SJ, Bartholome LT, Warren CS, Raymond NC. Binge eating disorder mediates links between symptoms of depression, anxiety, and caloric intake in overweight and obese women. J Obes. 2012;2012:407103. doi:10.1155/2012/407103

23. Affenito SG, Adams CH. Are eating disorders more prevalent in females with type 1 diabetes mellitus when the impact of insulin omission is considered? Nutr Rev. 2001;59:179-82. doi:10.1111/j.1753-4887.2001.tbo7010.x

24. Mannucci E, Ricca V, Mezzani B, Di Bernardo M, Piani F, Vannini R, et al. Eating attitude and behavior in IDDM patients. Diabetes Care. 1995;18:1503-4. doi:10.2337/diacare.18.11.1503

25. d'Emden H, Holden L, McDermott B, Harris M, Gibbons K, Gledhill A, et al. Disturbed eating behaviours and thoughts in Australian adolescents with type 1 diabetes. J Paediatr Child Health. 2013 Apr;49(4):E317-23. doi:10.1111/jpc.12014

26. Colton P, Olmsted M, Daneman D, Rydall A, Rodin G. Disturbed eating behavior and eating disorders in preteen and early teenage girls with type 1 diabetes: a case-controlled study. Diabetes Care. 2004;27:1654-9. doi:10.2337/diacare.27.7.1654

27. Stice E, Marti CN, Rohde P. Prevalence, incidence, impairment, and course of the proposed DSM-5 eating disorder diagnoses in an 8-year prospective community study of young women. J Abnorm Psychol. 2013 May;122(2):445-57. doi:10.1037/a0030679

28. da Luz FQ, Hay P, Touyz S, Sainsbury A. Obesity with comorbid eating disorders: associated health risks and treatment approaches. Nutrients. 2018 Jun 27;10(7). pii: E829. doi:10.3390/nu10070829

29. Rikani AA, Choudhry Z, Choudhry AM, Ikram H, et al. A critique of the literature on etiology of eating disorders. Ann Neurosci. 2013 Oct;20(4):157-61. doi:10.5214/ans.0972.7531.200409

30. Striegel-Moore RH, Bulik CM. Risk factors for eating disorders. Am Psychol. 2007 Apr;62(3):181-98. doi:10.1037/0003-066X.62.3.181

31. Takii M, Uchigata Y, Kishimoto J, Morita C, Hata T, Nozaki T, et al. The relationship between the age of onset of type 1 diabetes and the subsequent development of a severe eating disorder by female patients. Pediatr Diabetes. 2011 Jun;12(4 Pt 2):396-401. doi:10.1111/j.1399-5448.2010.00708.x

32. Wisting L, Froisland DH, Skrivarhaug T, Dahl-Jorgensen K, Ro O. Disturbed eating behavior and omission of insulin in adolescents receiving intensified insulin treatment: a nationwide population-based study. Diabetes Care. 2013 Nov;36(11):3382-7. doi:10.2337/dc13-0431

33. Smink FR, van Hoeken D, Oldehinkel AJ, Hoek HW. Prevalence and severity of DSM-5 eating disorders in a community cohort of adolescents. Int J Eat Disord. 2014 Sep;47(6):610-9. doi:10.1002/eat.22316

34. Ackard DM, Fulkerson JA, Neumark-Sztainer D. Prevalence and utility of DSM-IV eating disorder diagnostic criteria among youth. Int J Eat Disord 2007;40:409-17. doi:10.1002/eat.20389

35. Cruz-Saez S, Pascual A, Salaberria K, Echeburua E. Normal-weight and overweight female adolescents with and without extreme weight-control behaviours: emotional distress and body image concerns. J Health Psychol. 2015 Jun;20(6):730-40. doi:10.1177/1359105315580214

36. Sontag LM, Graber JA, Brooks-Gunn J, Warren MP. Coping with social stress: implications for psychopathology in young adolescent girls. J Abnorm Child Psychol. 2008;36(10):1159-74. doi:10.1007/s10802-008-9239-3

37. Mathisen TF, Bratland-Sanda S, Rosenvinge JH, Friborg O, Pettersen G, Vrabel KA, et al. Treatment effects on compulsive exercise and physical activity in eating disorders. J Eat Disord. 2018 Dec 13;6:43. doi:10.1186/s40337-018-0215-1

38. Vancampfort D, De Herdt A, Vanderlinden J, Lannoo M, Adriaens A, De Hert M, et al. The functional exercise capacity and its correlates in obese treatment-seeking people with binge eating disorder: an exploratory study. Disabil Rehabil. 2015;37(9):777-82. doi:10.3109/09638288.2014.942000 